\title{
Variability in the in situ bioavailability of Fe to bacterioplankton communities in the eastern subtropical Pacific Ocean
}

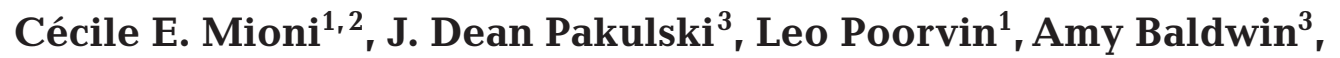 \\ Michael R. Twiss ${ }^{4}$, Wade H. Jeffrey ${ }^{3}$, Steven W. Wilhelm ${ }^{1, *}$ \\ ${ }^{1}$ Department of Microbiology, and ${ }^{2}$ Center for Environmental Biotechnology, 1414 West Cumberland, \\ The University of Tennessee, Knoxville, Tennessee 37996, USA \\ ${ }^{3}$ Center for Environmental Diagnostics and Bioremediation, University of West Florida, 11000 University Parkway, \\ Pensacola, Florida 32514, USA \\ ${ }^{4}$ Department of Biology, Clarkson University, Potsdam, New York 13699, USA
}

\begin{abstract}
It is now established that iron (Fe) availability controls phytoplankton productivity and community structure in ca. $50 \%$ of the Pacific Ocean's surface waters and that heterotrophic bacterioplankton may also be either directly or indirectly Fe-limited. Proxy indicators of Fe-stress are available for the phototrophic community (e.g. ferredoxin/flavodoxin ratios) but are lacking for the heterotrophic bacterioplankton. While current analytical tools provide valuable information with regard to micronutrient chemistry and speciation, they do not provide insight into the relative bioavailability of different Fe sources. We present the results of a field trial in an oceanic system of a tool that allows for the assessment of Fe bioavailability in natural systems: the Fe-responsive bioluminescent heterotrophic bacterial reporter. Fe bioavailability was monitored with this tool at the scale of the Eastern Pacific Basin during the mature phase of the El Niño event of 2002. The results demonstrate significant spatial variance, highlighted by regions of decreased Fe availability at equatorial stations along the transect. Using this tool in combination with radiotracer studies of bacterial growth and community Fe uptake, we provide insight into system Fe chemistry and the status of the heterotrophic bacterial community. Our results indicate that different environments with similar concentrations of total Fe can demonstrate different Fe bioavailabilities. Moreover, the small particulate size fraction $(0.2$ to $0.8 \mu \mathrm{m}$ ) appears to buffer artificially induced variations in Fe bioavailability, implying that studies of Fe bioavailability need to be extended beyond those in the dissolved $(<0.2 \mu \mathrm{m})$ size class.
\end{abstract}

KEY WORDS: Luminescent bacterial bioreporter · Iron bioavailability $\cdot$ HNLC $\cdot$ El Niño $\cdot$ Pacific Ocean Resale or republication not permitted without written consent of the publisher

\section{INTRODUCTION}

Concentrations of Fe in surface waters of the Pacific Ocean average ca. $0.26 \mathrm{nM}$, which is 5 times lower than the average concentration in the Atlantic Ocean (ca. $1.3 \mathrm{nM}$; Donat \& Bruland 1995) and results in the widespread limitation of primary productivity owing to the limited availability of this element. High-nutrient low-chlorophyll (HNLC) conditions occur in 3 pelagic areas of the Pacific basin, covering $40 \%$ of its surface waters (Whitfield 2001): the sub-Antarctic circumpolar waters in the Southern Ocean, the eastern equatorial Pacific, and the Gulf of Alaska in the sub-Arctic Pacific. These 3 areas coincide with divergence-driven regional upwelling of nutrient-rich deep waters, and in the cases of both high-latitude HNLC regions with strong seasonal deep mixing (Wells et al. 1995). Feenrichment experiments (Martin \& Gordon 1988, de 
Baar et al. 1990) and subsequently mesoscale fertilizations (reviewed by Boyd 2002, Tsuda et al. 2003) have unequivocally demonstrated that Fe availability controls primary production and community structure in these HNLC areas.

Such HNLC conditions are not constrained to offshore water. Indeed, on-deck experiments demonstrated that HNLC conditions also exist in coastal areas such as the Californian (Hutchins et al. 1998) and South American (Hutchins et al. 2002, Frank et al. 2003, Eldridge et al. 2004) upwelling systems. Recently, Fe has also been implicated in the large-scale 'brown water' diatom blooms that occur in Peruvian coastal waters (Bruland et al. 2005). Furthermore, other investigations suggest that Fe may also limit primary productivity in both the Central North (DiTullio et al. 1993) and South (Behrenfeld \& Kolber 1999) Pacific gyres, which were previously thought to be primarily limited by nitrogen.

The Eastern Tropical Pacific (ETP) is an area of interest because this highly productive region supports one of the world's largest industrial fisheries (Thorpe et al. 2000) and is periodically affected by the El NiñoSouthern Oscillation (ENSO) event, which causes a breakdown of these fisheries (Lehody et al. 1997, Chavez et al. 1999). Surface waters of the Eastern Pacific Ocean display significant variations in Fe concentrations on both a temporal and a spatial scale. These features offer ideal conditions under which to study the variations in Fe bioavailability (i.e. the portion and chemical speciation of $\mathrm{Fe}$ that can be absorbed, transported and utilized physiologically) between water masses with distinct biogeochemical signatures.

Although it has been well documented that both phytoplankton and bacterioplankton employ various strategies to acquire Fe from their environment(s), one major challenge remains for the determination of the chemical species of Fe that are assimilated from the environment (Wells et al. 1995). Until recently, the total concentration of dissolved Fe was used as a proxy of Fe availability to planktonic organisms. However, advances in analytical chemistry have shown that Fe speciation is very complex in aquatic systems. Indeed, chemical analyses have suggested that most of the dissolved Fe $\left(\mathrm{DFe}_{1}<0.2 \mu \mathrm{m}\right)$ in surface waters is complexed to organic ligands (e.g. Rue \& Bruland 1997) that may be released via grazing, virus-mediated cell lysis, or active production (Wilhelm \& Trick 1994, Wilhelm \& Suttle 1999, Poorvin et al. 2004). This suggests that the microbial activity greatly influences Fe speciation and that scavenging by different Fe-acquisition mechanisms may exert a control on Fe bioavailability at the community level. Because traditional analytical methods cannot resolve the bioavailable fraction of $\mathrm{Fe}$, various experiments have been performed to assess the bioavailability of $\mathrm{Fe}$ to marine bacterioplankton. These included size-fractionated Fe-uptake experiments, either coupled or not coupled with manipulation of bioavailable Fe (e.g. Tortell et al. 1996, Weaver et al. 2003, Wells \& Trick 2004), and the estimation of bacterial production via measurement of leucine (Leu) or thymidine (TdR) incorporation (Pakulski et al. 1996, Church et al. 2000, Kirchman et al. 2000). Results from these studies suggested that bacterioplankton may be directly or indirectly Fe-limited, where indirect limitation results from the reduced release of dissolved organic matter by the Fe-limited microbial community. As such, while these experiments provided insight into the Fe status of the global bacterioplankton population, they did not provide direct information on the linkage between microbial activity and Fe bioavailability in situ.

In this study, we used a dual approach to assess Fe bioavailability to bacterioplankton. We monitored variations in Fe bioavailability using the bioluminescent Fe-responsive bioreporter strain Pseudomonas putida FeLux (Mioni et al. 2003) during the mature 2002-03 ENSO event (October 2002) at the scale of the whole Eastern Pacific Basin, along a transect between the coasts of Chile $\left(26.3^{\circ} \mathrm{S}, 75.0^{\circ} \mathrm{W}\right)$ and Mexico $\left(17.5^{\circ} \mathrm{N}, 111.1^{\circ} \mathrm{W}\right)$. This bioreporter consists of an intact, living heterotrophic bacterial cell $(P$. putida) that has been genetically modified to produce a luminescent signal that is inversely correlated to Fe bioavailability (see Mioni et al. 2003 for further details). In parallel, we manipulated Fe availability at each station via a series of Fe addition and sequestration (using the hydroxamate siderophores desferrioxamine $\mathrm{B}[\mathrm{DFB}]$ and ferrichrome [FC]) experiments in size-fractioned seawater samples). As a complement to this approach, we used traditional techniques to examine the effects of solar irradiance on saturated Fe assimilation rates using ${ }^{55} \mathrm{Fe}$, and ${ }^{3} \mathrm{H}$-TdR and ${ }^{3} \mathrm{H}$-Leu to estimate bacterial production via radiotracer studies. Results from this study enabled us not only to assess changes in $\mathrm{Fe}$ bioavailability between various domains of the eastern Pacific, but also to infer the degree of in situ bacterial Fe limitation. While extrapolations from a single bacterial species to the entire community must be made with some caution, this tool nonetheless provides the best available proxy for $\mathrm{Fe}$ bioavailability to bacteria.

\section{MATERIALS AND METHODS}

Sample collection. For all stations, surface seawater was collected before sunrise to minimize effects of variations in light pre-exposure (Table 1). Hydro- 
Table 1. Sampling dates and local time, locations, and ambient parameters. $T$ : surface temperature; $\mathrm{S}$ : salinity

\begin{tabular}{|cccccc|}
\hline Stn & $\begin{array}{c}\text { Date } \\
(2002)\end{array}$ & $\begin{array}{c}\text { Time } \\
(\mathrm{h})\end{array}$ & Location & $\begin{array}{c}\mathrm{T} \\
\left({ }^{\circ} \mathrm{C}\right)\end{array}$ & $\begin{array}{c}\mathrm{S} \\
(\%)\end{array}$ \\
\hline BT01 & Oct 1 & $05: 53$ & $26.3^{\circ} \mathrm{S}, 75.0^{\circ} \mathrm{W}$ & 15.2 & 34.4 \\
BT02 & Oct 2 & $05: 34$ & $21.5^{\circ} \mathrm{S}, 77.0^{\circ} \mathrm{W}$ & 17.00 & 35.0 \\
BT03 & Oct 3 & $05: 35$ & $17.0^{\circ} \mathrm{S}, 79.0^{\circ} \mathrm{W}$ & 17.3 & 35.2 \\
BT04 & Oct 4 & $05: 29$ & $12.2^{\circ} \mathrm{S}, 81.4^{\circ} \mathrm{W}$ & 18.0 & 35.3 \\
BT05 & Oct 5 & $05: 27$ & $08.2^{\circ} \mathrm{S}, 83.5^{\circ} \mathrm{W}$ & 19.8 & 35.3 \\
BT06 & Oct 6 & $05: 29$ & $04.2^{\circ} \mathrm{S}, 85.0^{\circ} \mathrm{W}$ & 20.4 & 35.2 \\
BT07 & Oct 7 & $05: 34$ & $00.0^{\circ} \mathrm{S}, 86.0^{\circ} \mathrm{W}$ & 24.1 & 34.1 \\
BT08 & Oct 9 & $05: 30$ & $05.4^{\circ} \mathrm{N}, 92.4^{\circ} \mathrm{W}$ & 27.4 & 33.5 \\
BT09 & Oct 10 & $05: 30$ & $08.0^{\circ} \mathrm{N}, 96.0^{\circ} \mathrm{W}$ & 28.2 & 33.3 \\
BT10 & Oct 11 & $05: 30$ & $10.2^{\circ} \mathrm{N}, 99.4^{\circ} \mathrm{W}$ & 28.6 & 33.3 \\
BT11 & Oct 12 & $05: 30$ & $12.4^{\circ} \mathrm{N}, 103.1^{\circ} \mathrm{W}$ & 28.9 & 33.5 \\
BT12 & Oct 13 & $05: 30$ & $15.1^{\circ} \mathrm{N}, 105.5^{\circ} \mathrm{W}$ & 29.1 & 34.0 \\
BT13 & Oct 14 & $07: 15$ & $17.5^{\circ} \mathrm{N}, 111.1^{\circ} \mathrm{W}$ & 28.7 & 34.4 \\
& & & & & \\
\hline
\end{tabular}

graphic data were collected using the ship's Seabird CTD. For chlorophyll a (chl a) measurements, water samples were collected at $5 \mathrm{~m}$ depth with Niskin bottles mounted on the ship's CTD rosette. Chl a was quantified with a Turner Designs 10-AU fluorometer using the non-acidification protocol of Welschmeyer (1994). For experiments to characterize Fe concentration, Fe bioavailability, bacterial activity and Fe assimilation rates, seawater samples were collected using Go-Flo bottles at $10 \mathrm{~m}$ depth and subsequently homogenized in acid-cleaned polycarbonate carboys. Subsamples of unfiltered water were retained for measurement of total Fe concentrations and were stored frozen in acid-washed $125 \mathrm{ml}$ Teflon flasks for future analysis. Samples for bioreporter assays were filtered with acidwashed 0.8 or $0.2 \mu \mathrm{m}$ polycarbonate filters and processed immediately. All manipulations were performed in a laminar-flow Class 100 clean area with trace metal clean and aseptic techniques.

Total Fe analysis. Unfiltered non-acidified samples were stored at $4^{\circ} \mathrm{C}$ in the dark in Teflon bottles. Samples were acidified to $\mathrm{pH} 3.0$ with $\mathrm{HCl}$ (Fisher, trace metal grade), placed in acid-cleaned quartz tubes and irradiated by ultraviolet light (1200 W, $0.1 \mathrm{~m}$ distance from source) for $22 \mathrm{~min}$. Sample $\mathrm{pH}$ was adjusted to $\mathrm{pH}$ 8.0 using clean $\mathrm{NH}_{4} \mathrm{OH}$ prepared by isothermal distillation, and the samples were passed through a $1.1 \mathrm{ml}$ bed of Na-form Chelex-100 (100 to 200 mesh; Bio-Rad; $\mathrm{pH}$ 8), prepared using purified $\mathrm{NaOH}$ (Alfa-Aesar) at a

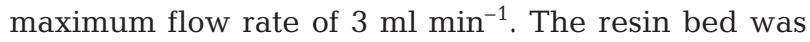
rinsed with $5 \mathrm{ml}$ of deionized water to remove salt water, and the chelated metals were stripped off the column by 7 successive additions of $1 \mathrm{ml}$ volumes of $1 \mathrm{M}$ nitric acid (Seastar). Fe content in the acid extract was determined by transversely heated Zeemancorrected graphite furnace atomic-absorption spectro- photometry (AA-600; PerkinElmer Instruments) using $\mathrm{MgNO}_{3}$ as a matrix modifier. Two similar volumes of NASS-5 certified reference seawater (National Research Council of Canada) were processed and analyzed with the samples. Blanks were determined by rinsing $1.1 \mathrm{ml}$ of Chelex-100 resin with deionized water and extracting with $1 \mathrm{M}$ nitric acid, as described above; Fe content in blanks was subtracted from the sample and certified reference values. NASS-5 values were $114 \%$ of the certified value; no Fe was detected in the resin blanks.

Culture conditions and shipboard assessment of Fe bioavailability using Pseudomonas putida FeLux. $P$. putida FeLux stock cultures were maintained in Pseudomonas Isolation Agar (Remel) supplemented with $50 \mu \mathrm{M} \mathrm{ll}^{-1}$ tetracycline and prepared for bioassays in the field as previously described (Mioni et al. 2005). Maintenance cultures were grown in the dark in a temperature-controlled incubator $\left(25^{\circ} \mathrm{C}\right)$ on an orbital shaker $(220 \mathrm{rpm})$. In accordance with the results from preliminary growth tests, the following amounts of Chelex-100 treated and filter-sterilized nutrient stocks were added to the seawater to make sure that the level of all nutrients but Fe was sufficient to support the growth of the bioreporters: $\mathrm{NH}_{4} \mathrm{NO}_{3}, 20 \mu \mathrm{M} ; \mathrm{NaH}_{2} \mathrm{PO}_{4}, 10 \mu \mathrm{M}$; glycerol, $1 \mu \mathrm{M}$; and vitamin mix (ESAW recipe, Berges et al. 2001), $100 \mu \mathrm{l}$. On the day prior to sampling at each station, $5 \mathrm{ml}$ of an overnight culture were transferred for acclimation to an acid-washed and microwave-sterilized $500 \mathrm{ml}$ polycarbonate Erlenmeyer flask filled with $95 \mathrm{ml}$ of filter-sterilized $(0.2 \mu \mathrm{m})$ enriched seawater collected off the coast of Chile. The resulting batch culture was subsequently incubated overnight at $25^{\circ} \mathrm{C}$ with shaking.

To assess the availability of Fe to our model bioreporter, we carried out a series of Fe amendment and removal experiments (vis-a-vis Eldridge et al. 2004). Fe 'removal' was accomplished by adding increasing concentrations of commercially available terrestrial siderophores (DFB or FC) that render Fe unavailable to Pseudomonas putida FeLux (Mioni et al. 2003, 2005). Siderophores were added to both 0.2 and $0.8 \mu \mathrm{m}$ filtered seawater samples. In parallel, we conducted Feenrichment experiments by supplementing the samples with up to $1.5 \mathrm{nM}$ inorganic Fe. The rationale for these 0.2 to $0.8 \mu \mathrm{m}$ pore sizes was the separation of the DFe fraction $(<0.2 \mu \mathrm{m})$ from the particulate fraction $(>0.2 \mu \mathrm{m})$, and therefore from the resident prokaryotic component (which predominates in the 0.2 to $1 \mu \mathrm{m}$ size fraction). Seawater was supplemented as indicated above. Acid-washed and microwave-sterilized Teflon Oakridge tubes were filled with $18 \mathrm{ml}$ aliquots of enriched and filtered seawater. Fe availability was manipulated by supplementing the seawater aliquots 
with either increasing concentrations of DFB or FC (up to $10 \mathrm{nM}$ ) or $\mathrm{FeCl}_{3}$ (up to $1.5 \mathrm{nM}$ ). The control treatment $(0 \mathrm{nM})$ was amended with neither DFB nor Fe and was therefore representative of the level of bioavailable $\mathrm{Fe}$ in the initial seawater sample. The experiment was initiated by adding $2 \mathrm{ml}$ of the overnight-acclimated $P$. putida FeLux culture to each replicate (initial cell concentration $\approx 10^{5}$ cells $\mathrm{ml}^{-1}$ ). Each treatment was repeated in triplicate (with results presented as mean $\pm \mathrm{SD}$ ). Light production was measured at 2, 4 and $6 \mathrm{~h}$ using a Zylux FB14 luminometer. In parallel, $950 \mu$ of each treatment was fixed with $50 \mu \mathrm{l}$ of glutharaldehyde $(2.5 \% \mathrm{v} / \mathrm{v})$ and kept refrigerated until bacteria were enumerated using epifluorescence microscopy (Hobbie 1977). Light production was normalized to reporter cells $\mathrm{ml}^{-1}$. Reported values are means of 3 replicate cultures for the time-point for which the signal was the strongest $(t=4 \mathrm{~h}$ ).

Fe uptake by natural communities. Saturated, sizefractionated $\mathrm{Fe}$ assimilation rates for marine assemblages were estimated at stations occupied during this study under light and dark conditions. Surface seawater was collected in acid-washed 2.71 polycarbonate bottles. Saturating amounts of ${ }^{55} \mathrm{Fe}\left(2 \mathrm{nmol} \mathrm{l}^{-1}\right.$ as ${ }^{55} \mathrm{FeCl}_{3}$ in $0.5 \mathrm{~mol} \mathrm{l}^{-1} \mathrm{HCl}$, ca. $42 \mathrm{mCi} \mathrm{mg}^{-1}$; New England Nuclear) were added to independent triplicate bottles, which were then incubated for $48 \mathrm{~h}$ at in situ temperatures. The bottles were either exposed to in situ light levels or maintained in darkness for the duration of the experiment. Following incubation, water was filtered in parallel through 0.2, 1.0 and $8.0 \mu \mathrm{m}$ nominal pore-size polycarbonate filters, which were then washed with Ti (III)-citrate-EDTA to remove surface associated ${ }^{55} \mathrm{Fe}$ (Hudson \& Morel 1989). Assimilated ${ }^{55} \mathrm{Fe}$ was measured using the Wallac Tri-Lux scintillation counter.

Bacterial productivity. Bacterial productivity was estimated by measuring tritiated $\left(\left[{ }^{3} \mathrm{H}\right]-\right)$ Leu incorporation and $\left[{ }^{3} \mathrm{H}\right]-\mathrm{TdR}$ incorporation following the method of Smith \& Azam (1992). [ $\left.{ }^{3} \mathrm{H}\right]-\mathrm{Leu}$ (final concentration: $10 \mathrm{nM}$ ) and [ $\left.{ }^{3} \mathrm{H}\right]$-TdR (final concentration: $10 \mathrm{nM}$ ) were dispensed in surface water samples amended or not (unamended control) with inorganic $\mathrm{Fe}\left(\mathrm{FeCl}_{3 i}\right.$ $1.5 \mathrm{nM}$ ). Three replicate samples were incubated for $4 \mathrm{~h}$ in the dark at in situ temperatures, along with 2 control samples killed with trichloroacetic acid (TCA; $5 \%$ final concentration). The incubation was stopped with TCA (5\% final concentration). Samples were rinsed via centrifugation in 5\% TCA, and the radioactivity incorporated into bacterial cells was then counted using a liquid scintillation counter. Activities within the killed controls were subtracted from reported values for the live samples.

Statistical analyses. Statistical analyses for all the data presented here were performed using SPSS (version 12) software. ANOVA and independent $t$ tests (2-tailed) were performed assuming equal variance on mean values. ANOVA (1-way) was used to establish the statistical significances of variation among different treatments. Dunnett's test was used to analyze the significance of the variation of means of a set of amended treatments relative to the control treatment mean (Corston \& Colman 2003). For all analyses, a $95 \%$ confidence interval $(\alpha=0.05)$ was used. Unless stated, results were considered significant at $\mathrm{p}<0.05$.

\section{RESULTS}

\section{Study area}

Samples were collected during the 'BRIDE of TABASCO' cruise (Bacterial Response to Irradiance Driven Energy-Translatitudinal Assessment of Biological Acclimation to Solar Conditions in the Ocean) from October 1 to October 14, 2002 (Fig. 1). The cruise track covered 3 sectors of the eastern Pacific Ocean: the southeastern Pacific (Stns BT01 to BT03), the equatorial Pacific (Stns BT04 to BT10) and the subtropical northeastern Pacific sectors (Stns B11 to BT13). The characteristics of each station are summarized in Table 1. Total Fe concentrations (dissolved + particulate) remained within a nanomolar range, spanning between 1.5 (BT11) and $10.2 \mathrm{nmol} \mathrm{kg}{ }^{-1}$ (BT06), except for Stn BT01 at which a sub-micromolar level was

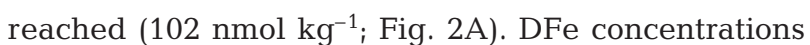
were not measured in the present study, but values reported in the literature for the study area are lowest for the stations located close to the equator (ca. $0.08 \mathrm{nM})$ and highest in the vicinity of Stns BT03 $(0.3 \mathrm{nM})$ and BT12 ( 0.40 nM) (Fig. 2A, Table 2). Chl a concentrations in surface waters were extremely low, ranging from 0.07 (BT12) to $0.39 \mu \mathrm{g} \mathrm{l}^{-1}$ (BT01; Fig. 2B). Two southern stations, surrounding a local upwelling cell (ca. 22 to $23^{\circ} \mathrm{S}$ ) off the coast of Chile, displayed the highest chl a concentrations: BT01 $\left(26^{\circ} \mathrm{S}, 0.39 \mu \mathrm{g} \mathrm{l}^{-1}\right)$ and BT04 $\left(14.5^{\circ} \mathrm{S}, 0.34 \mu \mathrm{g} \mathrm{l}^{-1}\right)$. The lowest chl a concentrations were observed north of the equator. These low chl a estimates coincided with observed changes in temperature and salinities.

The evolution of the biophysical parameters suggested that several water masses were crossed along the transect and that stations north of the equator may have been affected by the 2002 ENSO episode. However, the oligotrophic waters of the warm pool did not appear to have reached the southernmost part of the study area (i.e. Chilean coast). These observations agree with previous reports (McPhaden 2004). 


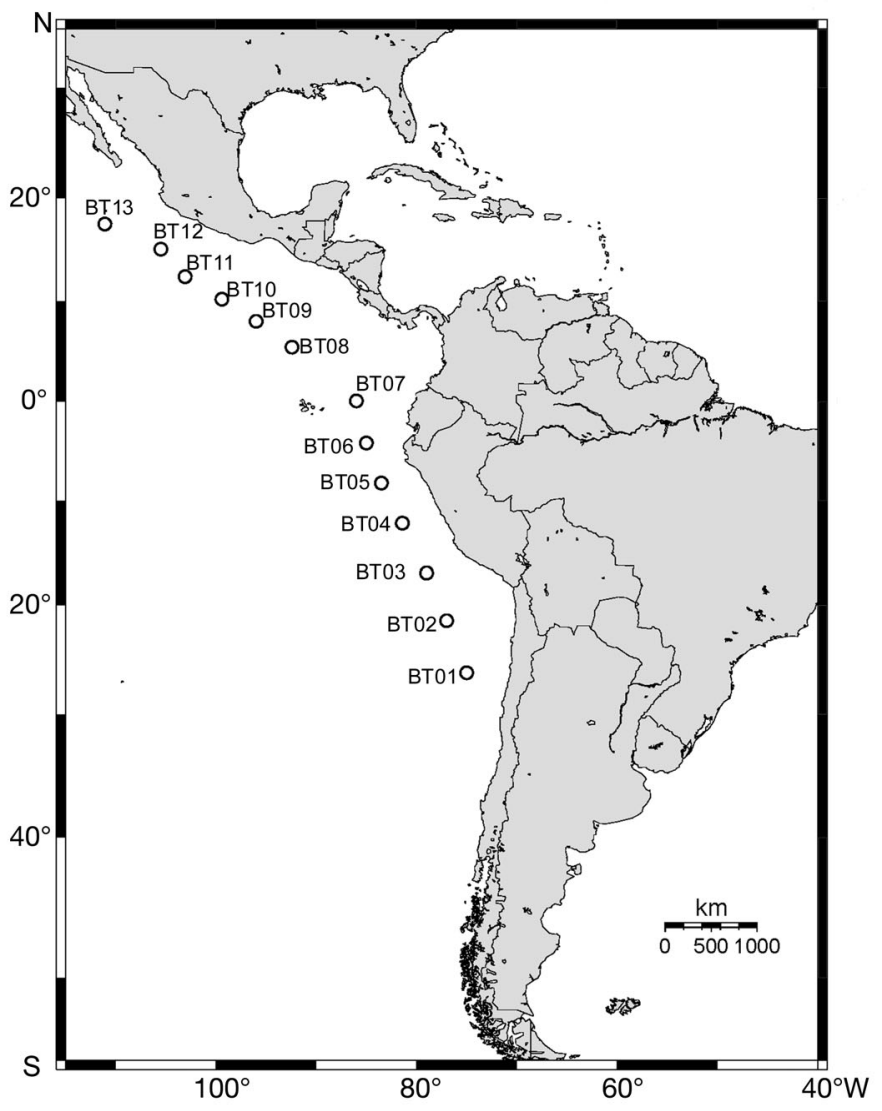

Fig. 1. Sampling stations in the Eastern Pacific Basin

\section{Monitoring bioavailable Fe using the Pseudomonas putida FeLux bioreporter}

Bioluminescence (as relative light units, Rlu) produced by the Fe-dependent bacterial bioreporter increased significantly (ANOVA, $\mathrm{p}=0.001$ ) from the coast off Chile $\left(B T 01 ; 0.031 \pm 0.001 \mathrm{Rlu}^{-1} \mathrm{Cll}^{-1} \mathrm{~s}^{-1}\right.$ ) to the central coast off Peru (BT04, $0.061 \pm 0.01 \mathrm{Rlu}$ cell ${ }^{-1} \mathrm{~s}^{-1}$; Fig. 2C). With the exception of the equatorial station (BT07), light production peaked at ca. $0.06 \mathrm{Rlu}_{\text {cell }}{ }^{-1} \mathrm{~s}^{-1}$ at stations located between the coast off Peru (BT04) and the Costa Rica Dome (BT09); no significant variations were found between these stations (ANOVA, $p=0.050$ ). Interestingly, a sharp and significant decrease (ANOVA, p < 0.001) in light production was observed within this zone at Stn BT07, which exhibited the lowest light production of the transect (ca. $0.014 \pm 0.001$ Rlu cell ${ }^{-1} \mathrm{~s}^{-1}$ ). Light production decreased significantly (ANOVA, $\mathrm{p}<0.001$ ) between the ETP stations and the northernmost station investigated (BT12; $0.028 \pm 0.005 \mathrm{Rlu} \mathrm{cell}^{-1} \mathrm{~s}^{-1}$ ) to reach a level similar to but significantly lower ( $t$-test, $\mathrm{p}=0.041$ ) than that observed at the southernmost station. This result suggests that Fe was more bioavailable to bioreporter cells north of the ETP system.

\section{Response of Pseudomonas putida FeLux to manipulations of bioavailable Fe}

The response of the Pseudomonas putida FeLux bioreporter to changing Fe bioavailability is shown in Fig. 3. Two groups of stations can be differentiated: (1) the stations at which addition of siderophore (DFB and/or FC) resulted in an increase in light production, suggesting that added siderophore decreased the level of available Fe originally present in seawater (BT01, BT04, BT05, BT07, and BT12); (2) the stations at which siderophore addition did not result in an increase
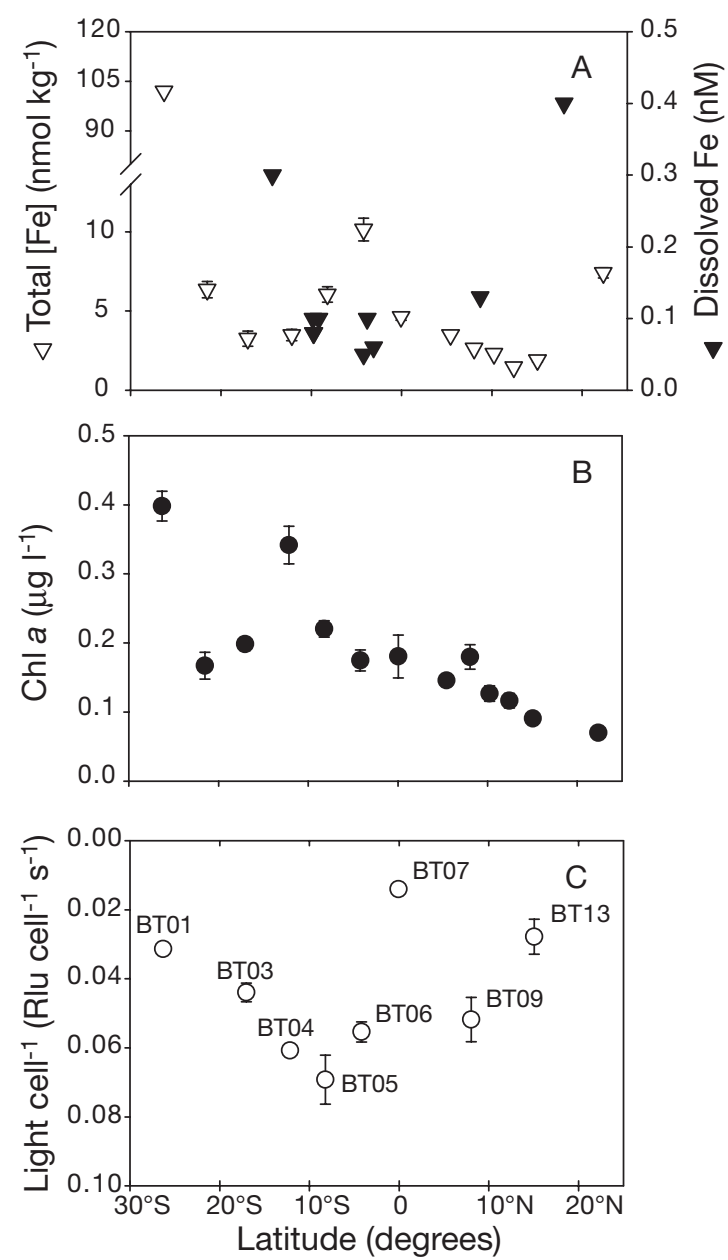

Fig. 2. Evolution of biophysical parameters along the 'BRIDE of TABASCO' transect. (A) Total Fe concentrations measured during this study and literature values for the study area. Each value (except BT01, $\mathrm{n}=1$ ) is the mean from duplicate analyses of the same extract. Error bars: range of duplicate extractions and analyses. DFe (dissolved Fe) data referenced in Table 2. (B) Chl a. Error bars: $\pm \mathrm{SD}(\mathrm{n}=3)$. (C) Normalized bioluminescence in non-amended $0.2 \mu \mathrm{m}$-filtered seawater samples. Error bars: \pm SD $(n=3)$. Note that the $y$-axis for normalized bioluminescent signal values is inverted to facilitate comparison with DFe concentrations. Station numbers where bioreporter analyses were performed are indicated 
Table 2. Dissolved Fe (DFe) concentration in surface waters of the Pacific Ocean at sampling sites located in the vicinity of 'BRIDE of TABASCO' stations (adapted from Table A2 in de Baar \& de Jong 2001). N/A: not available

\begin{tabular}{|c|c|c|c|c|}
\hline Location (Stn) & $\begin{array}{l}\text { Depth range } \\
\text { (m) }\end{array}$ & $\begin{array}{l}\text { DFe range } \\
\left(\mathrm{nmol} \mathrm{l}^{-1}\right)\end{array}$ & $\begin{array}{c}\text { Mean [DFe] } \\
\left(\mathrm{nmol} \mathrm{l}^{-1}\right)\end{array}$ & Source \\
\hline \multicolumn{5}{|c|}{ Subtropical North Pacific Gyre } \\
\hline$\sim 35^{\circ} \mathrm{N}, 122-139^{\circ} \mathrm{W}$ & $0-100$ & $0.01-0.16$ & $\sim 0.06$ & Martin \& Gordon (1988) \\
\hline $36^{\circ} \mathrm{N}, 123^{\circ} \mathrm{W}$ & $0-80$ & $0.20-0.70$ & $\sim 0.40$ & Gordon et al. (1982) \\
\hline$\sim 37^{\circ} \mathrm{N}, 124^{\circ} \mathrm{W}$ & $25-100$ & $0.14-1.19$ & - & Landing \& Bruland (1987) \\
\hline \multicolumn{5}{|l|}{ Eastern North tropical Pacific } \\
\hline $18^{\circ} \mathrm{N}, 108^{\circ} \mathrm{W}(\mathrm{BT} 13)$ & $15-100$ & $0.01-0.57$ & $\sim 0.40$ & Landing \& Bruland (1987) \\
\hline $18^{\circ} \mathrm{N}, 108^{\circ} \mathrm{W}(\mathrm{BT} 13)$ & $0-60$ & $0.13-0.73$ & $\sim 0.40$ & Gordon et al. (1982) \\
\hline $19^{\circ} \mathrm{N}, 105^{\circ} \mathrm{W}$ & $15-250$ & $0.66-5.71$ & $\sim 2.00$ & Landing \& Bruland (1987) \\
\hline $8.7^{\circ} \mathrm{N}, 90.6^{\circ} \mathrm{W}(\mathrm{BT} 08)$ & $5-15$ & N/A & 0.13 & Frank et al. (2003) \\
\hline \multicolumn{5}{|l|}{ Equatorial Pacific Ocean } \\
\hline $0-1.5^{\circ} \mathrm{N}, 92^{\circ} \mathrm{W}$ & 0 & $0.01-1.50$ & - & Martin et al. (1994) \\
\hline $1^{\circ} \mathrm{N}, 92^{\circ} \mathrm{W}$ & $20-150$ & $0.03-0.22$ & $\sim 0.10$ & Gordon et al. (1998) \\
\hline$\sim 0^{\circ} \mathrm{N}, 91-93^{\circ} \mathrm{W}$ & $20-150$ & $0.02-0.22$ & $\sim 0.10$ & Gordon et al. (1998) \\
\hline $0.5^{\circ} \mathrm{N}-2^{\circ} \mathrm{S}, 89^{\circ} \mathrm{W}(\mathrm{BT} 07)$ & $20-150$ & $0.02-0.22$ & $\sim 0.10$ & Gordon et al. (1998) \\
\hline $3.1^{\circ} \mathrm{S}, 86.3^{\circ} \mathrm{W}$ (BT06) & $\sim 7$ & N/A & 0.06 & Eldridge et al. (2004) \\
\hline $3.8^{\circ} \mathrm{S}, 85.3^{\circ} \mathrm{W}(\mathrm{BT} 06)$ & $5-15$ & N/A & 0.10 & Frank et al. (2003) \\
\hline$\sim 4.2^{\circ} \mathrm{S}, 83.0^{\circ} \mathrm{W}($ BT06) & $5-15$ & N/A & & Bruland et al. (2005) \\
\hline $4-7^{\circ} \mathrm{S}, 105-110^{\circ} \mathrm{W}$ & 0 & $0.02-0.04$ & 0.021 & Rue \& Bruland (1997) \\
\hline $5^{\circ} \mathrm{S}, 90^{\circ} \mathrm{W}$ & 0 & $<0.05-0.14$ & $0.07 \pm 0.03$ & Gordon et al. (1998) \\
\hline \multicolumn{5}{|l|}{ Eastern South tropical Pacific } \\
\hline $9.2^{\circ} \mathrm{S}, 80.5^{\circ} \mathrm{W}(\mathrm{BT} 05)$ & $\sim 7$ & N/A & 0.10 & Eldridge et al. (2004) \\
\hline $9.7^{\circ} \mathrm{S}, 81.5^{\circ} \mathrm{W}(\sim \mathrm{BT} 05)$ & $5-15$ & N/A & 0.08 & Bruland et al. (2005) \\
\hline $9.8^{\circ} \mathrm{S}, 81.6^{\circ} \mathrm{W}(\mathrm{BT} 05)$ & $\sim 7$ & N/A & 0.10 & Eldridge et al. (2004) \\
\hline $9.8^{\circ} \mathrm{S}, 81.6^{\circ} \mathrm{W}(\sim \mathrm{BT} 05)$ & $5-15$ & N/A & 0.08 & Bruland et al. (2005) \\
\hline $14.3^{\circ} \mathrm{S}, 78.4^{\circ} \mathrm{W}(\sim \mathrm{BT} 03 / 04)$ & $5-15$ & N/A & 0.30 & Frank et al. (2003) \\
\hline $15.2^{\circ} \mathrm{S}, 76^{\circ} \mathrm{W}$ & $\sim 7$ & N/A & 0.08 & Eldridge et al. (2004) \\
\hline
\end{tabular}

of luminescence (BT03, BT06, and BT09), possibly because the level of available Fe remained high despite addition of DFB or because the bioreporter cells could not be pushed into further physiological stress.

At Stn BT01, light production increased between the treatment amended with $1.5 \mathrm{nM}$ of Fe and the treatment supplemented with $3 \mathrm{nM}$ of $\mathrm{DFB}\left(\mathrm{R}^{2}=0.999\right.$; slope $=-0.004$ ). Light production in +3 nM DFB (Dunnett's test, $\mathrm{p}=0.022$ ) and $+1.5 \mathrm{nM}$ Fe (Dunnett's test, $\mathrm{p}=0.031$ ) treatments was significantly higher and lower, respectively, compared with that measured in the non-amended control. Light production appeared to decrease upon addition of $10 \mathrm{nM} \mathrm{DFB}$, but this decrease was not significant relative to the $+3 \mathrm{nM}$ DFB treatment ( $t$-test, $\mathrm{p}=0.0549$ ), suggesting that DFB additions greater than $3 \mathrm{nM}$ were sufficient to complex most of the bioavailable Fe in the sample. Above this threshold concentration, bioreporter cells may have been too severely starved to undergo the luciferase reaction and subsequently to generate light.

In contrast to Stn BT01, there was no perceptible response to the lowest $(<3 \mathrm{nM})$ DFB additions at Stns BT04, BT05, BT07 and BT12. Instead, light production significantly increased upon addition of $>3 \mathrm{nM}$ DFB
(Table 3). Futhermore, the addition of Fe at nanomolar levels did not result in any significant decrease in bioluminescent signal except at Stn BT07. This suggests that the bioreporter cells did not perceive an increase in Fe bioavailability in the Fe-amended treatments. At Stn BT12, amendment of the seawater samples with FC did not result in a significant alteration of the light production relative to DFB additions within the range of concentrations tested (Dunnett's test, $\mathrm{p}>0.05$ ).

Table 3. Statistical analyses for Stns BT04, BT05, BT07 and BT12: threshold concentration of DFB ([DFB]) at which the luminescent signal increased significantly compared with the control; p-values obtained for light production in control vs. threshold [DFB] treatment; \% increase in bioluminescent signal relative to control

\begin{tabular}{|llccc|}
\hline Stn & Location & $\begin{array}{c}\text { Threshold } \\
{[\mathrm{DFB}]} \\
\left(\mathrm{nmol} \mathrm{l}^{-1}\right)\end{array}$ & $\begin{array}{c}\mathrm{p}- \\
\text { value }\end{array}$ & $\begin{array}{c}\text { Lumin- } \\
\text { escence } \\
\text { increase (\%) }\end{array}$ \\
\hline BT04 & Central Peru & 4 & 0.001 & 18.4 \\
BT05 & North Peru & 4 & 0.009 & 13.6 \\
BT07 & Equator & 3 & 0.005 & 29.6 \\
BT12 & NW Mexico & 25 & $<0.001$ & 56.4 \\
\hline
\end{tabular}




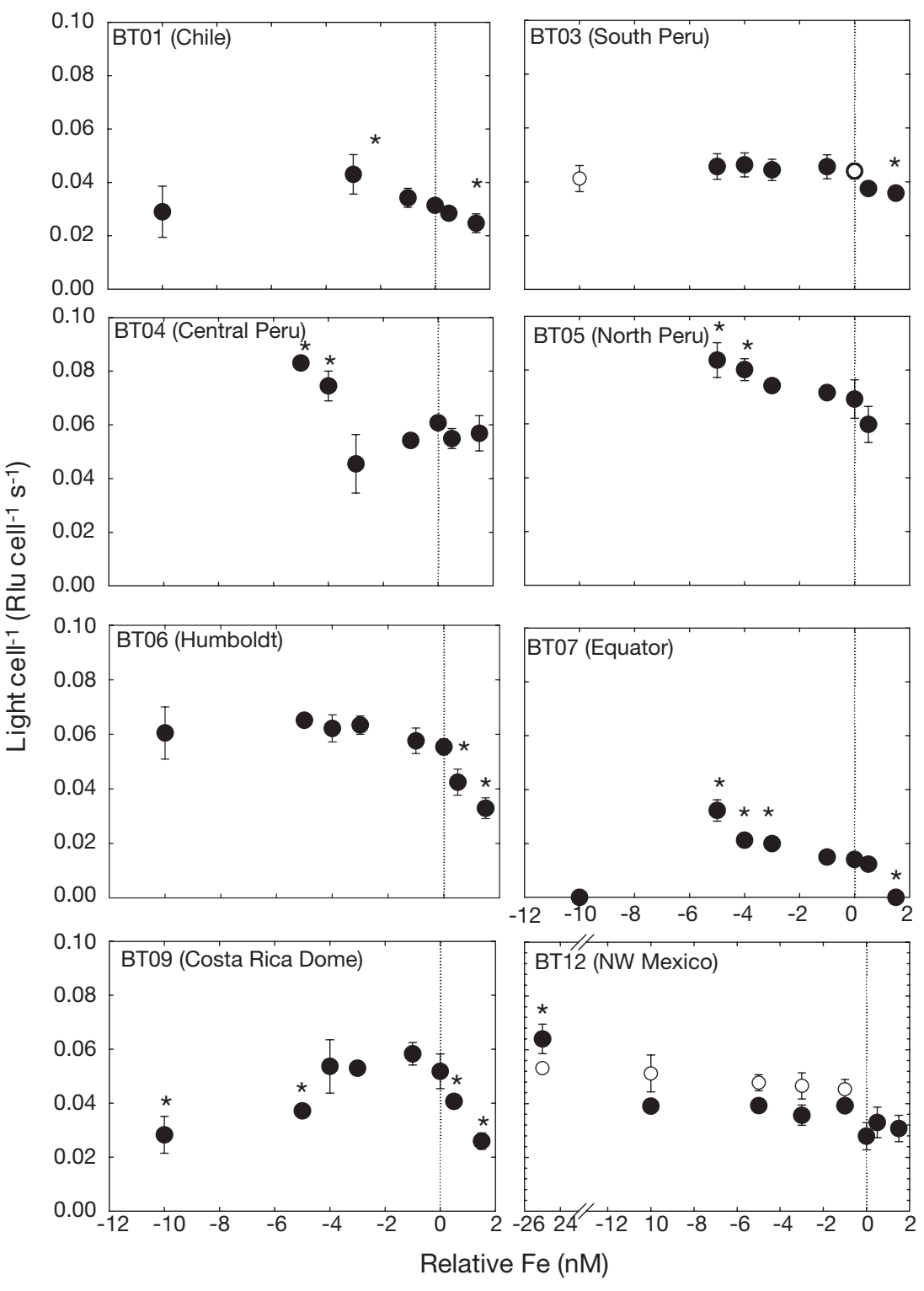

Fig. 3. Response of Pseudomonas putida FeLux bioreporter to Fe manipulation along a $\mathrm{S}$ to NNW field track in the eastern Pacific. Normalized luminescence vs. concentration of relative Fe for $0.2 \mu \mathrm{m}$ filtered samples amended with DFB $(\bullet), F C(O)$ or $\mathrm{FeCl}_{3}$. Increased light production after DFB addition suggests that this siderophore decreased the level of available Fe originally present in seawater. Addition of DFB at other stations did not result in an increase in luminescence, possibly because the level of available Fe remained high despite addition of DFB or because stronger ligands than DFB $\left(\log K_{\mathrm{FeL}}>21.6\right)$ may have been present in the water. Samples significantly different from the control are indicated $\left({ }^{*} \mathrm{p}<0.05\right.$; Dunnett's test $)$; error bars: $\pm \mathrm{SD}(\mathrm{n}=3)$

(Stn BT09). At Stn BT03, the addition of FC yielded a result similar to that of the addition of DFB (Dunnett's test, $\mathrm{p}>0.05\left[\mathrm{DFB}_{(1-5 \mathrm{nM})} \cdot \mathrm{Control}^{-1}\right]$; Dunnett's test, $\mathrm{p}>0.05\left[\mathrm{FC}_{(1-5 \mathrm{nM})} \cdot\right.$ control $\left.^{-1}\right]$ ). At Stn BT09, the concentration of bioavailable Fe may have been the lowest, owing to the dramatic decrease in light production upon addition of either high ( $>4 \mathrm{nM})$ DFB concentrations (Dunnett's test, p < $\left.\left.0.001 \mathrm{DFB}_{(5-10 \mathrm{nM})} \mathrm{Control}^{-1}\right]\right)$ or subnanomolar Fe levels (Dunnett's test, $\mathrm{p}=0.011\left[\mathrm{Fe}_{(0.5 \mathrm{nM})}\right.$ control $\left.^{-1}\right], \mathrm{p}<0.001$ $\left.\left[\mathrm{Fe}_{(1.5 \mathrm{nM})} \mathrm{Control}^{-1}\right]\right)$. By contrast, the significant but small decrease in the luminescent signal upon $\mathrm{Fe}$ addition at Stn BT03 (Dunnett's test, p = 0.026 $\left[\mathrm{Fe}_{(0.5 \mathrm{nM})}\right.$ control $\left.^{-1}\right] ; \mathrm{p}=0.038\left[\mathrm{Fe}_{(1.5 \mathrm{nM})}\right.$ control $\left.^{-1}\right]$ ) suggests that the bioreporter cells were close to replete condition.

\section{Influence of the ambient bacterial community on Fe bioavailability}

To investigate the effect of the small particulate fraction on $\mathrm{Fe}$ bioavailability, we conducted similar Fe removal/addition experiments in $0.8 \mu \mathrm{m}$ filtered water at 3 stations: BT04, BT07, and BT09 (Fig. 4). At all stations, the 'small particulate $\mathrm{Fe}^{\prime}$ treatments $(<0.8 \mu \mathrm{m})$ displayed significantly different luminescent signals relative to those observed for the 'DFe' samples $(<0.2 \mu \mathrm{m})$. At Stn BT04, the luminescent signal decreased slightly but significantly ( $t$ test; $\mathrm{p}=0.049$ ) when bioreporter cells were incubated in $0.8 \mu \mathrm{m}$ filtered seawater. In contrast, the $0.8 \mu \mathrm{m}$ treatments displayed a significantly higher luminescent signal for both Stns BT07 ( $t$-test, $\mathrm{p}<0.001)$ and BT09 ( $t$-test, $\mathrm{p}=0.042)$. These changes were especially prominent at the

The bioluminescent signal did not increase significantly in response to the addition of DFB at Stns BT03, BT06, and BT09. However, a significant decrease in light production was observed when inorganic Fe was added. When more than $5 \mathrm{nM}$ of DFB was added to the sample, light production remained stable (Stn BT06) or significantly decreased compared with the control equatorial station (BT07), because the signal increased by a factor of 2 between the 0.2 and the $0.8 \mu \mathrm{m}$ filtered treatments. Although significant, variations in bioreporter response were less pronounced at both Stn BT04 (-25\%) and Stn BT09 (+20\%). Within the range of concentrations tested, addition of Fe or DFB to the $0.8 \mu \mathrm{m}$ filtered seawater sample did 


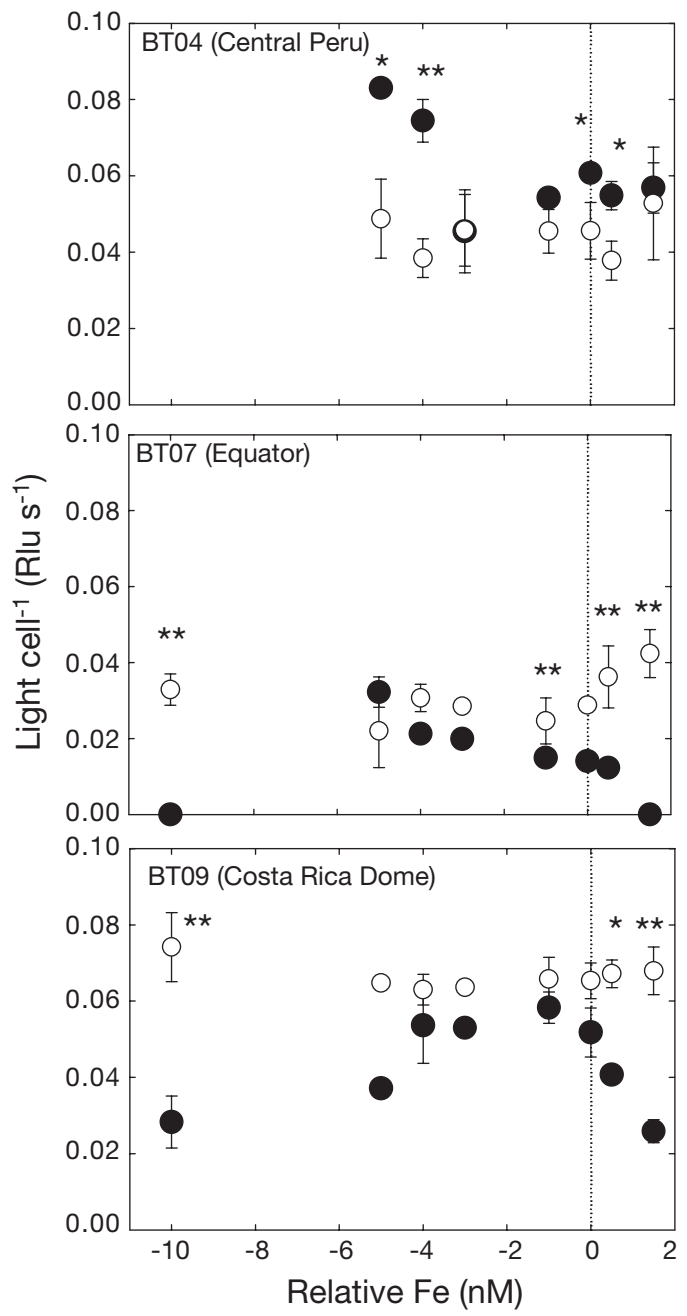

Fig. 4. Manipulation of Fe availability at Stns BT04, BT07, and BT09 in $0.2 \mu \mathrm{m}(\bullet)$ and $0.8 \mu \mathrm{m}(0)$ filtered seawater samples. 'Particulate + dissolved' samples statistically different from the 'dissolved' sample are indicated $\left({ }^{*} \mathrm{p}<0.05 ;{ }^{* *} \mathrm{p}<0.001\right.$; $t$-test). Error bars: $\pm \mathrm{SD}(\mathrm{n}=3)$

not significantly alter the bioluminescent signal relative to the control (Dunnett's test, $\mathrm{p}>0.05$ ).

\section{Saturated Fe assimilation rates}

Light-driven assimilation rates of $\mathrm{Fe}$ were highest at the equatorial Pacific stations (BT04 to BT10), ranging from $\sim 90$ to $400 \mathrm{pM} \mathrm{d}^{-1}$ (Table 4). Fe assimilation rates were low at the northern (BT13, $\left.9.3 \pm 2.1 \mathrm{pM} \mathrm{d}^{-1}\right)$ and southern (BT01, $8.3 \pm 6.1 \mathrm{pM} \mathrm{d}^{-1}$ ) extremes of the transect, which not surprisingly corresponded to the stations with the highest concentrations of total $\mathrm{Fe}$ in the water column. With the exception of 2 stations (BT03 and BT05), $\mathrm{Fe}$ assimilation rates were consistently highest for the 0.2 to $1.0 \mu \mathrm{m}$ size class (paired $t$-tests, $\mathrm{p}=0.040$ light, $\mathrm{p}=0.024$ dark), indicative of the important role of the microbial community in the marine Fe cycle.

Relative to dark rates, Fe uptake rates in the light were lower for most southern stations, and higher for the majority of the northern stations where exposure of the community to ambient light enhanced Fe assimila-
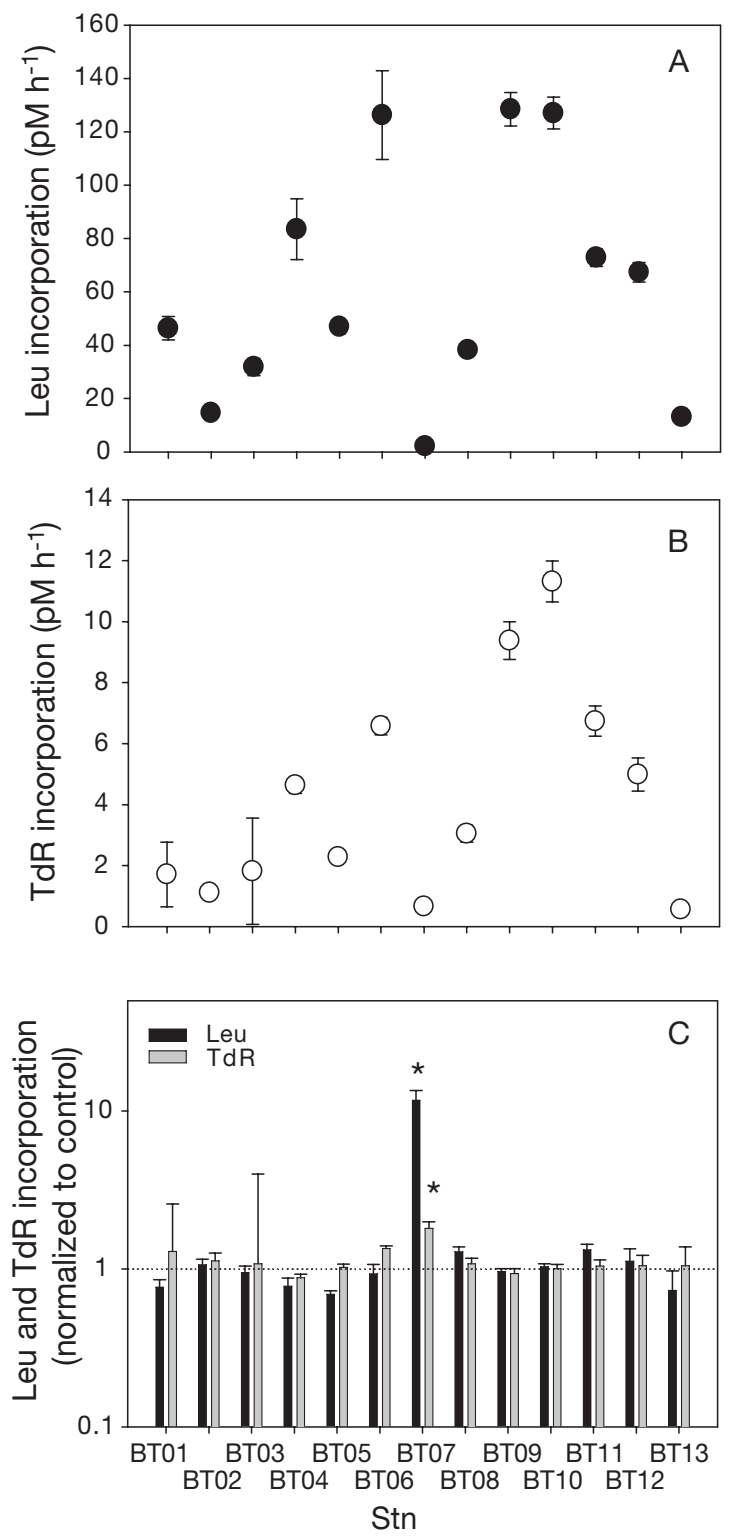

Fig. 5. Bacterial production along the 'BRIDE of TABASCO' transect. (A) $\left[{ }^{3} \mathrm{H}\right]-$ Leu incorporation in unamended samples. (B) $\left[{ }^{3} \mathrm{H}\right]-\mathrm{TdR}$ incorporation in unamended samples. (C) Effect of Fe addition on $\left[{ }^{3} \mathrm{H}\right]$-Leu and $\left[{ }^{3} \mathrm{H}\right]$-TdR incorporations. Data plotted as the ratio of bacterial production in treatments amended with $1.5 \mathrm{nM}$ of $\mathrm{FeCl}_{3}$ to that of control (nonamended). TdR and Leu incorporation rates that differed significantly between Fe-amended treatments compared and the control are indicated $\left({ }^{*} \mathrm{p}<0.05 ; t\right.$-test). Error bars: $\pm \mathrm{SD}$ $(\mathrm{n}=3)$ 
Table 4. Size-fractionated Fe assimilation rates $\left(\mathrm{pM} \mathrm{d}^{-1}\right)$ for stations occupied during the transect. Cellular ${ }^{55} \mathrm{Fe}$ internalization rates (titanium-citrate-EDTA washed samples; $\mathrm{n}=3 ; \pm \mathrm{SD}$ ) for experiments carried out under dark and ambient light conditions; p-values resulting from $t$-tests for each light-dark treatment are also given

\begin{tabular}{|c|c|c|c|c|c|c|c|c|c|}
\hline \multirow{2}{*}{ Stn } & \multicolumn{3}{|c|}{$0.22-1 \mu \mathrm{m}$} & \multicolumn{3}{|c|}{$-1-8 \mu \mathrm{m}-$} & \multirow[b]{2}{*}{ Light } & \multirow{2}{*}{$\begin{array}{c}->8 \mu \mathrm{m} \\
\text { Dark }\end{array}$} & \multirow[b]{2}{*}{$\mathrm{p}$} \\
\hline & Light & Dark & $\mathrm{p}$ & Light & Dark & $\mathrm{p}$ & & & \\
\hline BT01 & $8.3 \pm 6.1$ & $10.0 \pm 10.6$ & 0.816 & $1.7 \pm 0.6$ & $2.2 \pm 0.5$ & 0.351 & $0.3 \pm 0.1$ & $0.8 \pm 0.1$ & 0.005 \\
\hline BT03 & $50.4 \pm 6.5$ & $85.0 \pm 22.0$ & 0.059 & $61.0 \pm 14.5$ & $50.0 \pm 3.9$ & 0.274 & $21.6 \pm 4.5$ & $21.5 \pm 3.7$ & 0.965 \\
\hline BT04 & $111.4 \pm 7.3$ & $203.8 \pm 48.8$ & 0.032 & $74.5 \pm 10.7$ & $107.3 \pm 39.5$ & 0.238 & $42.4 \pm 9.9$ & $29.0 \pm 4.8$ & 0.104 \\
\hline BT05 & $90.8 \pm 30.9$ & $110.7 \pm 29.9$ & 0.466 & $120.6 \pm 39.0$ & $119.6 \pm 8.6$ & 0.970 & $57.8 \pm 17.3$ & $47.8 \pm 2.5$ & 0.860 \\
\hline BT07 & $164.6 \pm 33.1$ & $164.0 \pm 20.5$ & 0.980 & $88.0 \pm 13.7$ & $66.5 \pm 24.7$ & 0.259 & $23.7 \pm 3.9$ & $33.7 \pm 9.2$ & 0.158 \\
\hline BT08 & $241.0 \pm 25.5$ & $262.4 \pm 36.7$ & 0.454 & $47.3 \pm 6.7$ & $44.1 \pm 8.3$ & 0.629 & $7.5 \pm 2.1$ & $9.7 \pm 1.0$ & 0.180 \\
\hline BT09 & $402.7 \pm 38.1$ & $565.4 \pm 69.0$ & 0.023 & $148.8 \pm 44.0$ & $149.2 \pm 13.6$ & 0.988 & $15.0 \pm 5.7$ & $8.5 \pm 0.4$ & 0.120 \\
\hline BT10 & $393.0 \pm 15.2$ & $386.1 \pm 79.5$ & 0.891 & $80.5 \pm 7.8$ & $83.6 \pm 3.3$ & 0.553 & $6.3 \pm 1.1$ & $4.6 \pm 0.3$ & 0.058 \\
\hline BT11 & $79.2 \pm 72.7$ & $54.8 \pm 20.7$ & 0.606 & $48.0 \pm 35.7$ & $34.9 \pm 19.4$ & 0.604 & $10.1 \pm 3.5$ & $7.7 \pm 1.2$ & 0.330 \\
\hline BT12 & $46.1 \pm 18.2$ & $66.4 \pm 47.4$ & 0.527 & $16.0 \pm 3.2$ & $19.5 \pm 3.5$ & 0.284 & $5.5 \pm 1.4$ & $4.0 \pm 0.6$ & 0.146 \\
\hline BT13 & $9.3 \pm 2.1$ & $4.1 \pm 1.4$ & 0.023 & $2.1 \pm 0.4$ & $2.1 \pm 0.8$ & 0.921 & $0.3 \pm 0.1$ & $0.1 \pm 0.0$ & 0.047 \\
\hline
\end{tabular}

tion by $>100 \%$ in both the 0.2 to $1.0 \mu \mathrm{m}$ and $>8.0 \mu \mathrm{m}$ size classes (Table 3). In total, there was no significant difference between the light and dark treatments within size classes $(0.2$ to $1.0 \mu \mathrm{m}, \mathrm{p}=0.108 ; 1.0$ to $8.0 \mu \mathrm{m}, \mathrm{p}=0.838 ;>8.0 \mu \mathrm{m}, \mathrm{p}=0.286$ ); however, within stations there were some significant differences $(\mathrm{p}<$ 0.005), including higher rates of Fe-uptake under both light and dark conditions for the 0.2 to 1.0 and $>8.0 \mu \mathrm{m}$ size classes.

\section{Bacterial production}

Bacterial production varied by ca. 20- to 62-fold (Fig. 5A,B). The highest bacterial production rates were observed at Stn BT06 and at the northern stations of the equatorial Pacific sector (BT09 to BT11) and the lowest at the equatorial station (BT07) and a station located in the subtropical northeastern Pacific (BT13). We did not observe any clear correlation between total Fe concentrations and chl a concentrations or bacterial production.

Bacterial production was not affected by the addition of $1.5 \mathrm{nM}$ Fe in our dark incubations, except for the equatorial station (BT07) where both leucine and thymidine incorporations in Fe-amended treatments differed significantly ( $t$-test; Leu: $\mathrm{p}<0.001$; TdR: $\mathrm{p}=$ 0.001) from rates in unamended controls (Fig. 5C). At the ETP stations, at which the lowest total Fe concentration was observed, Leu and TdR incorporation rates were not correlated. At Stns BT08 and BT11, TdR incorporation rates in Fe-amended samples did not differ from rates in unamended controls ( $t$-test; BT08: $\mathrm{p}=$ 0.230; BT011: $\mathrm{p}=0.530$ ), while Leu incorporation rates were significantly enhanced by $1.5 \mathrm{nM}$ Fe enrichment ( $t$-test; BT08: $\mathrm{p}=0.004 ;$ BT011: $\mathrm{p}=0.011)$. At Stn BT06, TdR incorporation was enhanced in Fe-amended samples ( $t$-test; $\mathrm{p}<0.001)$, while Leu incorporation rates were not affected by Fe enrichment $(t$-test; $\mathrm{p}=$ 0.485).

\section{DISCUSSION}

Several conclusions can be drawn from the present study: (1) that a gradient of Fe bioavailability persisted in the eastern Pacific Ocean along the course of the transect, (2) that changes in Fe bioavailability to heterotrophic bacteria do not always correlate with gross changes in total phytoplankton biomass (as measured by chl a) or total Fe concentrations, (3) that a manipulation of $\mathrm{Fe}$ bioavailability using xenosiderophores (e.g. DFB and FC) in conjunction with bioreporter analyses provides valuable information with regard to the degree to which Fe is bioavailable in environmental samples, and (4) that the small particulate pool $(0.2$ to $0.8 \mu \mathrm{m})$ can act as both a sink and a source of bioavailable Fe. These points are developed in the discussion that follows.

\section{Assessment of Fe bioavailability along the transect}

Little is known of the Fe-status of the heterotrophic bacterioplankton in the Eastern Pacific Basin. A mesoscale experiment (IronEx II) in oceanic waters of the Equatorial Pacific (ca. $10^{\circ}$ west of our transect) reported an increase in bacterial abundance in response to $\mathrm{Fe}$ enrichment, suggesting that heterotrophic bacteria were at least indirectly Fe-limited (Cochlan 2001). In contrast, Fe-enrichment experiments performed in the Central Equatorial Pacific suggested that carbon limitation controls bacterioplankton growth (Kirchman \& Rich 1997); however, Fe effects 
were not directly tested in that study. Previous reports of the Peru upwelling suggested that phytoplankton are Fe-limited rather than Fe-starved in this region (Eldridge et al. 2004) and that the natural Fe gradient correlates with shifts in the bacterial community (Eldridge 2004), suggesting that bacterioplankton are affected by Fe bioavailability.

Bioreporter analyses presented here clearly show a decrease in DFe bioavailability as one transects toward the equator, either from the Chilean coast to the central coastal area off Peru or from the coastal waters northwest off Mexico to the Costa Rica Dome. Manipulations of Fe bioavailability further suggest that Fe was not limiting in the surface waters off Chile and the northern station (Stn BT13). In contrast, stations located within the Peruvian coastal system displayed the highest bioluminescent signal, suggesting that Fe bioavailability was the lowest in this region. These results are consistent with previous observations (Bruland et al. 2005) that suggest a gradient from mild HNLC water offshore of central Peru ([DFe] $0.3 \mathrm{nM}$ ) to the most severely Felimited HNLC regime at the northern border of the Peru Current ([DFe] 0.05 to $0.1 \mathrm{nM}$ ).

This gradient in Fe bioavailability is also evident in the size-fractionated Fe assimilation data, which show enhanced rates of $\mathrm{Fe}$ acquisition that parallel the observed levels of Fe-deficiency from the bioreporter analyses. Saturated Fe uptake rates were highest at the stations closest to the equator (BT07 to BT10), and lowest at the stations where the bioreporter analyses suggested that the community was Fe-replete (BT01 and BT13). Moreover, although bioavailable Fe levels estimated from bioreporter analyses do not correlate with our estimated total Fe concentrations $(R=0.255)$, they appear to correlate well with the DFe concentrations reported in the literature (Fig. 2, Table 1).

Unfortunately, no DFe concentrations or Fe speciation data are presently available for the equatorial station (BT07) to explain the observed drop in luminescence. Although it is difficult to discard the likelihood that the seawater sample was contaminated, the low light production might reflect a severe Fe starvation of the bioreporter cells that resulted in a decrease in cellular energy, which is necessary to sustain the luciferase reaction. Indeed, Fe starvation affects electron transport systems and the metabolic activity of bacteria (Tortell et al. 1996, Kirchman et al. 2003) and light emission remains a costly process (up to 20 ATP molecules per emitted photon) that could be a metabolic burden to the host bacterial bioreporter cells (van der Meer et al. 2004). Therefore, the efficiency of the bioluminescent response of the Pseudomonas putida FeLux bioreporter may have been significantly altered at Stn BT07. Although the total Fe concentration at this location was relatively high $\left(4.6 \pm 0.2 \mathrm{nmol} \mathrm{kg}{ }^{-1}\right)$, bac- terial production was significantly stimulated by $\mathrm{Fe}$ enrichment, suggesting a direct Fe limitation.

Taken together, these results confirm that Pseudomonas putida FeLux is sensitive and selective enough to detect trace variations in Fe bioavailability in complex environments such as seawater. Although bioreporter cells appeared to be too Fe-starved to generate an adequate bioluminescent response at Stn BT07, they remained operational at other stations located in a region characterized by the lowest DFe concentrations predicted from recent models (Moore et al. 2002). Moreover, independent laboratory and field experiments suggest that the analytical window of $P$. putida FeLux is relevant to most environmental conditions, including HNLC conditions (bioluminescence linearly related to bioavailable Fe for Fe[III] concentrations spanning from $37 \mathrm{pM}$ to $18.6 \mathrm{nM}$; Mioni et al. 2005). Although not perfect, this diagnostic tool is far preferable to simple chemical measures of total Fe. Indeed, our results indicate that different environments with similar concentrations of total Fe display completely different Fe bioavailability. The decoupling observed between Fe bioavailability (as measured by the $P$. putida FeLux bioreporter) and chl a suggests that Fe speciation or factors other than total Fe concentration may be involved in controlling phytoplankton biomass (e.g. the limitation of other nutrients, light, or control exerted by temperature or grazing pressure etc.). Previous studies effectively demonstrated that the ability to acquire Fe from various organic Fe complexes varies greatly among taxonomic groups and even among species (Hutchins et al. 1999, Weaver et al. 2003).

By coupling bioreporter analyses to the manipulation of Fe bioavailability and bacterial production, we were able to gain more insight into the pool of bioavailable Fe. Stations investigated in the present study could be classified in 3 main groups:

(1) Fe-sufficient stations, represented by Stns BT01 and BT12. Interestingly, Stn BT01 was located close to a known upwelling that supplies nutrient-rich deep waters (Romero \& Hebbeln 2003). One may therefore assume that upwelled waters at this station may have been a significant source of 'new' Fe that was highlly bioavailable to Pseudomonas putida FeLux. Bacterial production rates measured at this station seem to corroborate this assumption. Bacterial production rates were relatively low, but addition of Fe alone did not stimulate bacterial activities (in term of Leu or TdR incorporation), which indicates that the ambient bacterioplankton community was not primarily limited by Fe but perhaps by other nutrients (e.g. dissolved organic carbon). By contrast, Stn BT12 was located in the most oligotrophic waters (in terms of chl a) at the edge of the warm pool where picoplankton are expected to dominate the biomass. 
(2) Stations displaying Fe stress but not Fe starvation (Stns BT03, BT04, BT05, BT06, and BT09). These stations cover both waters offshore of the Peru upwelling system (BT03, BT04, BT05, BT06) and waters of the Costa Rica Dome (BT09), which are known to be characterized by transient Fe-limiting conditions (Chavez et al. 1999, Hutchins et al. 2002, Frank et al. 2003, Eldridge et al. 2004, Bruland et al. 2005). Resident planktonic species may be expected to be adapted to such limiting conditions, and thus be better competitors for $\mathrm{Fe}$ as illustrated by the high bacterial activity (Leu and TdR incorporation rates). Stns BT06 and BT09 can be distinguished from the previous subgroup by the decrease in light production upon Fe addition. Curiously, bacterial production rates at these 2 stations suggest that bacterial activities were high and that the endogenous bacterial community was not directly Fe-limited. At these stations, bacterial growth and activity may have been uncoupled (i.e. protein turnover was independent of net growth rates), which could complicate the interpretation of Leu incorporation rates. Indeed, it was previously reported that Leu incorporation rates tend to overestimate biomass production when growth rates are slow (Kirchman 2001). Stn BT06 is known to be located in a severely Fe-limited HNLC area ([DFe] $0.05 \mathrm{nM}$; Bruland et al. 2005), and bacterioplankton may be adapted to such conditions.

(3) An Fe-starved station (BT07). Stn BT07 was located in equatorial seawater where picoplankton dominate the plankton assemblage (Coale et al. 1996, Cochlan 2001). Bacterial production rates in Feamended samples vs. controls suggest that Fe was directly limiting at the equator.

In summary, these results indicated that the bioavailability of Fe is location-dependent (varying with species composition, DFe concentration etc.). Although our results do not resolve the debate between indirect or direct Fe limitation, they clearly indicate that the pool of bioavailable Fe to heterotrophic bacteria such as Pseudomonas putida FeLux differs among regions and that subtle differences exist among bioavailable Fe pools that would appear at first sight to be similar. Our results also highlighted the linkage between Fe availability and $\mathrm{Fe}$ speciation in marine systems, because changes in speciation (via DFB addition) markedly influenced the response of our bioreporter. This observation is in agreement with previous reports that suggested a feedback relationship between the plankton community and the bioavailable Fe pool. For example, the structure of the organic ligands derived from marine biota influences Fe availability to the planktonic community (Hutchins et al. 1999, Weaver et al. 2003) and, as a consequence, may influence the community composition (Eldridge 2004).

\section{Effect of the small particulate fraction on Fe bioavailability}

Previously, we reported that at least a fraction of particulate $\mathrm{Fe}$ is bioavailable to bacterioplankton in aquatic ecosystems (Mioni et al. 2003). In the present study, the relationship between the particulate Fe pool and the bioavailable Fe pool appears more complex. Our results suggest that the small particulate size class (0.2 to $0.8 \mu \mathrm{m})$ can effectively influence Fe bioavailability by acting as both a source (as at Stn BT04) and a sink (e.g. at Stns BT07 and BT09). Moreover, the particulate fraction appears to buffer artificially induced variations in Fe bioavailability at all stations investigated, indicating that it plays a key role in controlling the bioavailable Fe pool in marine systems. Therefore, our results highlight the complexity of the feedback relationships between Fe bioavailability and the particulate size class.

Because the heterotrophic bacterioplankton were included in this small particulate size class, our results may reflect the level of cooperative or competitive production of siderophores. Recent models suggest that cooperation is advantageous - even when relatedness is low -in the case of global competition (i.e. when DFB is added at a high level in seawater samples that contain several bacterial subpopulations; Griffin et al. 2004). Such cooperative siderophore production may explain why Fe bioavailability did not vary in the $0.8 \mu \mathrm{m}$ filtered treatments when the system was pushed into further Fe-limiting conditions.

Although early reports claimed that only dissolved inorganic species of $\mathrm{Fe}$ were bioavailable to aquatic microbes, several lines of evidence suggest that particulate Fe could be an important source of Fe to microbial organisms in oceanic environments. Most Fe in surface seawater (up to $99 \%$ in the equatorial Pacific) is in the particulate size class, and most of the DFe fraction is colloidal (Sunda 2001). Photochemical processes at seawater $\mathrm{pH}$ have been shown to increase the solubility of otherwise inert Fe crystalline oxides (Wells et al. 1991), and as such their bioavailability to microorganisms. Other studies suggested that Fe hydroxides can support Fe uptake as a result of their fast dissolution kinetics (Kuma \& Matsunaga 1995), and that such hydroxides can adsorb to the cell surface where they subsequently undergo bioreductive dissolution (Sunda 2001). This mode of Fe acquisition may be used by cyanobacteria such as Trichodesmium spp. (Sunda 2001). Siderophores also increase the solubility and dissolution kinetics of Fe oxides over a wide $\mathrm{pH}$ range, and may therefore increase the bioavailability of Fe in aquatic systems (Kraemer 2004). Moreover, most microbial organisms are capable of phagotrophy, which could be used to acquire Fe from the particulate 
fraction (Sunda 2001). Experiments on the autotrophic flagellate Ochromonas sp. in the Pacific Ocean demonstrated that this organism could acquire Fe directly from the particulate fraction by ingesting bacteria (Maranger et al. 1998). In the present study, contrasting results suggest that the importance of the particulate pool is dependent on location (i.e. community structure, total $\mathrm{Fe}$, nutrients etc.) in a similar fashion as to what is observed for the dissolved $(<0.2 \mu \mathrm{m}) \mathrm{Fe}$ pool.

Results presented here highlight the complexity of the bioavailable Fe pool in marine environments, and suggest that the speciation of Fe as well as the biological community itself influences Fe bioavailability to the bacterioplankton. A decoupling between Fe bioavailability and bacterial production or phytoplankton biomass suggests that other factors besides bioavailable Fe (e.g. the structure of the organic-binding ligands) may influence the community structure.

Acknowledgements. We thank S. Ghobrial, J. Meador, and the captain and crew of RV 'Nathaniel B. Palmer' for assistance at sea. We also thank J. Rinta-Kanto and D. Piotrowski for helpful comments during the preparation of the manuscript. This research was supported by a University of Tennessee Center for Environmental Biotechnology Graduate Fellowship to C.E.M., National Science Foundation award OCE-0327730 to M.R.T. and National Sciences Foundation awards OCE-000298 and OCE-0526159 to S.W.W.

\section{LITERATURE CITED}

Behrenfeld M, Kolber Z (1999) Widespread iron limitation of phytoplankton in the south Pacific Ocean. Science 283: 840-843

Berges JA, Franklin DJ, Harrison PJ (2001) Evolution of an artificial seawater medium: improvements in enriched seawater, artificial water over the last two decades. J Phycol 37:1138-1145

Boyd PW (2002) The role of iron in the biogeochemistry of the Southern Ocean and equatorial Pacific: a comparison of in situ iron enrichments. Deep-Sea Res II 49:1803-1821

Bruland KW, Rue EL, Smith GJ, DiTullio GR (2005) Iron, macronutrients and diatom blooms in the Peru upwelling regime: brown and blue waters of Peru. Mar Chem 3:81-103

Chavez FP, Strutton PG, Friederich CE, Feely RA, Feldman GC, Foley DC, McPhaden MJ (1999) Biological and chemical response of the equatorial Pacific Ocean to the 1997-98 El Niño. Science 286:2126-2131

Church MJ, Hutchins DA, Ducklow HW (2000) Limitation of bacterial growth by dissolved organic matter and iron in the Southern Ocean. Appl Environ Microbiol 66:455-466

Coale KH, Fitzwater SE, Gordon RM, Johnson KS, Barber RT (1996) Control of community growth and export production by upwelled iron in the equatorial Pacific Ocean. Nature 379:621-624

Cochlan WP (2001) The heterotrophic bacterial response during a mesoscale iron enrichment experiment (IronExII) in the eastern Equatorial Pacific Ocean. Limnol Oceanogr 46: 428-435

Corston R, Colman AM (2003) A crash course in SPSS for windows, 2nd edn. Blackwell Publishing, Malden, MA

de Baar HJW, de Jong JTM (2001) Distributions, sources and sinks of iron in seawater. In: Turner DR, Hunter KA (eds) The biogeochemistry of iron in seawater. Wiley, New York, p 123-254

de Baar HJW, Buma AGJ, Nolting RF, Cadée GC, Jacques G, Tréguer PJ (1990) On iron limitation of the Southern Ocean: experimental observations in the Weddell and Scotia Seas. Mar Ecol Prog Ser 65:105-122

DiTullio GR, Hutchins DA, Bruland KW (1993) Interaction of iron and major nutrient controls phytoplanlton growth and species composition in the Tropical North Pacific Ocean. Limnol Oceanogr 38:495-508

Donat JR, Bruland KW (1995) Trace elements in the oceans. In: Balbu B, Steinnes E (eds) Trace metal in natural waters. CRC Press, Boca Raton, FL

Eldridge ML (2004) The effects of Fe on plankton in HNLC regions of the world's oceans. $\mathrm{PhD}$ dissertation. University of Tennessee, Knoxville

Eldridge ML, Trick CG, Alm MB, DiTullio GR, Rue EL, Bruland KW, Hutchins DA, Wilhelm SW (2004) Phytoplankton community response to a manipulation of bioavailable iron in HNLC waters of the subtropical Pacific Ocean. Aquat Microb Ecol 35:79-91

Frank VM, Bruland KW, Hutchins DA, Brzezinski MA (2003) Iron and zinc effects on silicic acid and nitrate uptake kinetics in three high-nutrient, low-chlorophyll (HNLC) regions. Mar Ecol Prog Ser 252:15-33

Gordon RM, Martin JH. Knauer GA (1982) Iron in the northeast Pacific waters. Nature 299:611-612

Gordon RM, Johnson KS, Coale KH (1998) The behaviour of iron and other trace elements during the IronExI and PlumEx experiments in the Equatorial Pacific. Deep-Sea Res II 45:995-1041

Griffin AS, West SA, Buckling A (2004) Cooperation and competition in pathogenic bacteria. Nature 430:1024-1027

Hobbie JE, Daley RJ, Jasper S (1977) Use of nucleopore filters for counting bacteria by fluorescence microscopy. Appl Environ Microbiol 33:1225-1228

Hudson RJM, Morel FMM (1989) Distinguishing between extra- and intracellular iron in marine phytoplankton. Limnol Oceanogr 36:1113-1120

Hutchins DA, Di Tullio GR, Zhang Y, Bruland KW (1998) An Fe limitation mosaic in the California upwelling regime. Limnol Oceanogr 43:1037-1054

Hutchins DA, Witter AW, Butler A, Luther GW III (1999) Competition among marine phytoplankton for different chelated iron species. Nature 400:858-861

Hutchins DA, Hare CE, Weaver RS, Zhang Y and 11 others (2002) Phytoplankton iron limitation in the Humboldt Current and Peru Upwelling. Limnol Oceanogr 47:997-1011

Kirchman DL (2001) Measuring bacterial biomass production and growth rates from leucine incorporation in natural aquatic environments. In: Paul JH (ed) Methods in microbiology, Vol 30, Marine microbiology. Academic Press, San Diego, CA, p 227-237

Kirchman DL, Rich JH (1997) Regulation of bacterial growth rates by dissolved organic carbon and temperature in the equatorial Pacific Ocean. Microb Ecol 33:11-20

Kirchman DL, Cottrell MT, Hutchins DA, Weeks D, Bruland KW (2000) Carbon versus iron limitation of bacterial growth in the California upwelling regime. Limnol Oceanogr 45:1681-1688

Kirchman DL, Hoffman KA, Weaver R, Hutchins DA (2003) Regulation of growth and energetics of a marine bacterium by nitrogen source and iron availability. Mar Ecol Prog Ser 250:291-296

Kraemer SM (2004) Iron oxide dissolution and solubility in the presence of siderophores. Aquat Sci 66:3-18 
Kuma KS, Matsunaga K (1995) Availability of colloidal ferric oxides to coastal marine phytoplankton. Mar Biol 122: $1-11$

Landing WM, Bruland KW (1987) The contrasting biogeochemistry of iron and manganese in the Pacific Ocean. Geochim Cosmochim Acta 51:29-43

Lehody P, Bertignac M, Hampton J, Lewis A, Picaut J (1997) El Niño Southern Oscillation and tuna in the western Pacific. Nature 389:715-718

Maranger R, Bird DF, Price NM (1998) Iron acquisition by photosynthetic marine phytoplankton from ingested bacteria. Nature 396:248-251

Martin JH, Gordon RM (1988) Northeast Pacific iron distributions in relation to phytoplankton productivity. Deep-Sea Res 35:341-343

Martin JH, Coale KH, Johnson KS, Fitzwater SE and 40 others (1994) Testing the iron hypothesis in ecosystems of the equatorial Pacific Ocean. Nature 371:123-129

McPhaden MJ (2004) Evolution of the 2002/2003 El Niño. Bull Am Meteorol Soc 85:677-695

Mioni CE, Howard AM, DeBruyn JM, Bright NG, Twiss MR, Applegate BM, Wilhelm SW (2003) Characterization and field trials of a bioluminescent bacterial reporter of iron bioavailability. Mar Chem 83:31-46

Mioni CE, Handy SM, Ellwood MJ, Twiss MR, McKay RML, Boyd PW, Wilhelm SW (2005) Tracking a natural shift in bioavailable $\mathrm{Fe}$ in a marine system: a first estimate using a heterotrophic bacterial bioreporters. Global Biogeochem Cycles 19:GB4S25, doi:10.1029/2005GB002476

Moore JK, Doney SC, Glover DM, Fung IY (2002) Iron cycling and nutrient-limitation patterns in surface waters of the World Ocean. Deep-Sea Res II 49:463-507

Pakulski JD, Coffin RB, Kelley CA, Holder SL, Downer R, Aas P, Lyons MM, Jeffrey WH (1996) Iron stimulation of Antarctic bacteria. Nature 383:133-134

Poorvin L, Rinta-Kanto JM, Hutchins DA, Wilhelm SW (2004) Viral release of iron and its bioavailability to marine plankton. Limnol Oceanogr 49:1734-1741

Romero O, Hebbeln D (2003) Biogenic silica and diatom thanatocoenosis in surface sediments below the PeruChile Current: controlling mechanisms and relationship with productivity of surface waters. Mar Micropaleontol 48:71-90

Rue EL, Bruland KW (1997) The role of organic complexation

Editorial responsibility: Gerhard Herndl,

Den Burg, Texel, The Netherlands on ambient iron chemistry in the equatorial Pacific Ocean and the response of a mesoscale iron addition experiment. Limnol Oceanogr 42:901-910

Smith DC, Azam F (1992) A simple, economical method for measuring bacterial synthesis rates in seawater. Mar Microb Food Webs 6:107-114

Sunda SW (2001) Bioavailability and bioaccumulation of iron in the sea. In: Turner DR, Hunter KA (eds) The biogeochemistry of iron in seawater. Wiley, New York, p 41-84

Thorpe A, Ibarra AA, Reid C (2000) The new economic model and marine fisheries development in Latin America. World Dev 28:1689-1702

Tortell PD, Maldonado MT, Price NM (1996) The role of heterotrophic bacteria in iron-limited ocean ecosystems. Nature 383:330-332

Tsuda A, Takeda S, Saito H, Nishioka J and 22 others (2003) A mesoscale iron enrichment in the western subarctic Pacific Induces a large centric diatom bloom. Science 300: 958-961

van der Meer JR, Tropel D, Jasper M (2004) Illuminating the detection chain of bacterial bioreporters. Environ Microbiol 6:1005-1020

Weaver RS, Kirchman DL, Hutchins DA (2003) Utilization of iron/organic ligand complexes by marine bacterioplankton. Aquat Microb Ecol 31:227-239

Wells ML, Trick CG (2004) Controlling iron availability to phytoplankton in iron-replete coastal waters. Mar Chem 86:1-13

Wells ML, Mayer LM, Donard OFX, Sierra MMD, Ackelson SG (1991) The photolysis of colloidal iron in the oceans. Nature 353:248-250

Wells ML, Price NM, Bruland KW (1995) Iron chemistry in seawater and its relationship to phytoplankton. Mar Chem 48:157-182

Welschmeyer NA (1994) Fluorometric analysis of chlorophyll $a$ in the presence of chlorophyll $b$ and pheopigments. Limnol Oceanogr 39:1985-1992

Whitfield M (2001) Interactions between phytoplankton and trace metals in the ocean. Adv Mar Biol 41:3-128

Wilhelm SW, Suttle CA (1999) Viruses and nutrient cycles in the sea. BioScience 49:781-788

Wilhelm SW, Trick CG (1994) Iron-limited growth of cyanobacteria: multiple siderophore production is a common response. Limnol Oceanogr 39:1979-1984

Submitted: December 18, 2006; Accepted: January 3, 2007

Proofs received from author(s): February 19, 2007 